\title{
Rhizobium fredii sp. nov., a Fast-Growing Species That Effectively Nodulates Soybeans
}

\author{
MICHAEL H. SCHOLLA ${ }^{1 *}$ AND GERALD H. ELKAN ${ }^{2}$ \\ Department of Biology, Memphis State University, Memphis, Tennessee $38152^{1}$ and Department of Microbiology, North \\ Carolina State University, Raleigh, North Carolina $27650^{2}$
}

\begin{abstract}
A new species, Rhizobium fredii, is proposed for fast-growing root nodule bacteria isolated from soybeans. The type strain was isolated from a root nodule of Glycine max growing in Honan Province, China, and is designated strain USDA 205 (= ATCC $35423=$ PRC 205). This new species is differentiated from currently recognized Rhizobium and Bradyrhizobium species by deoxyribonucleic acid hybridization comparisons, plant specificity, generation times, antibiotic resistance, and serology. The strains of $R$. fredii are differentiated into two proposed chemovars, $R$. fredii chemovar fredii chemovar nov. and $R$. fredii chemovar siensis chemovar nov., by deoxyribonucleic acid hybridization tests, growth in the presence of erythromycin $(20 \mu \mathrm{g} / \mathrm{ml})$, final $\mathrm{pH}$ of yeast extract-mannitol medium, and serology.
\end{abstract}

Bacteria which form effective nitrogen-fixing nodules on the roots of leguminous plants are presently classified into two genera, Rhizobium and Bradyrhizobium $(6,8)$. Differentiation of these genera is based upon the cross-inoculation group concept $(6,8)$. The distinguishing features between the two genera are differences in physiology when the organisms are grown on medium containing yeast extract and mannitol and the plant host groups which are nodulated. These differences have been reviewed elsewhere $(3,4,6,8)$. Rhizobium spp. are considered to be fast growing, with generation times of less than $6 \mathrm{~h}$, whereas Bradyrhizobium strains have generation times in excess of $6 \mathrm{~h}(6,8)$. The genus Rhizobium presently includes three species, Rhizobium meliloti, Rhizobium loti (5), and Rhizobium leguminosarum (8), which includes the former species Rhizobium trifolii and Rhizobium phaseoli (7). Bradyrhizobium presently has one species, Bradyrhizobium japonicum, and includes strains that are capable of effectively nodulating lupines and soybeans (6). Also included within the bradyrhizobia is the cowpea miscellany (6).

Recently, a new group of fast-growing rhizobia which nodulate soybeans was isolated from mainland China (9). A list of these strains and appropriate references are shown in Table 1. Comparative studies of growth rate and acid production on yeast extract-mannitol medium (YEM) $(9,13$, $15)$, plant cross-inoculation $(9,15)$, plasmid profiles $(10,12)$, location of nitrogen fixation (nif) genes (10), location of nodulation genes (12), susceptibility to antibiotics (15), physiological characteristics $(9,13,15)$, vitamin requirements (15), tolerance to $\mathrm{NaCl}(13,15)$, diffentiation on litmus milk (13), and deoxyribonucleic acid (DNA) hybridization (14) indicate that this group has cultural characteristics of species in the fast-growing genus Rhizobium and symbiotic characteristics of species in the slow-growing genus Bradyrhizobium. DNA homology indicates that these fast-growing, soybean-nodulating strains are not genetically related to the type strain of any of the previously recognized species, but the strains in each proposed chemovar are related among themselves (14). Several investigators have indicated that this group of bacteria does not conform to the criteria for any of the previously recognized species $(9,10,12-16)$. Therefore, we describe a new species of fast-growing rhizobia which nodulate soybeans.

\footnotetext{
* Corresponding author
}

The importance of the cross-inoculation concept as a taxonomic tool has recently been deemphasized $(5,6)$ because the results of several investigations have indicated that the traits of nodulation and nitrogen fixation are plasmid mediated $(1,2,10-12)$. The importance of physiological differences is presently emphasized and is the basis for the recent reclassification of the slow-growing rhizobia into the genus Bradyrhizobium $(6,7)$. Since the fast-growing soybean-nodulating strains are physiologically similar to other fast-growing root nodule bacteria, we believe that the new strains are appropriately assigned to the genus Rhizobium.

The selection of a species name for root nodule bacteria traditionally has indicated the plant host group $(5,6,8)$. Therefore, the fast-growing soybean strains might be named Rhizobium japonicum. This name was used previously for Bradyrhizobium japonicum (6). The confusion created by using the same name to describe two different groups of organisms is readily evident. Therefore, we propose that the new species be named in honor of the late Edwin Broun Fred (1887-1981). E. B. Fred pioneered Rhizobium research in the United States while serving as bacteriologist at Virginia Polytechnic Institute and State University from 1907 to 1913. In 1913, he joined the faculty of the University of Wisconsin, where he continued his many contributions to this field.

Rhizobium fredii sp. nov. Rhizobium fredii (fred'i.i. M.L. gen. n. fredii of E. B. Fred) cells are gram negative, nonsporeforming, and rod shaped. Motility is exibited by only a small proportion ( 1 to $5 \%$ ) of the strains; this proportion is increased when the organisms are cultured on soft agar. Cells from late log phase to stationary phase YEM cultures tend to become large and pleomorphic.

Within 7 days, colonies on YEM agar plates containing bromthymol blue are between 1.0 and $5.0 \mathrm{~mm}$ in diameter, produce an acidic reaction, and are circular, convex, and entire. Extracellular polysaccharide production is minimal, but some strains produce watery colonies. The amount of growth at $28^{\circ} \mathrm{C}$ on YEM agar containing $2 \% \mathrm{NaCl}$ is variable, but all strains are inhibited at a concentration of $3 \%$. Inhibition of all strains is evident at $\mathrm{pH} 9.5$, but they grow well at $\mathrm{pH} 4.5$.

Gelatinase, galactosidase, and 6-phosphogluconate dehydrogenase are produced. All strains grow on arabinose, cellobiose, dulcitol, fructose, fumarate, galactose, gluconate, glucose, glycerol, lactose, malate, mannose, pyruvate, raffinose, rhamnose, succinate, sucrose, trehalose, and $x y-$ 
TABLE 1. Fast-growing soybean-nodulating rhizobia included in R. fredii

\begin{tabular}{|c|c|}
\hline Strain & Reference(s) \\
\hline USDA 191 (= PRC 440). & $9, \frac{10,12,13}{16}$ \\
\hline USDA $192(=$ OB2) & $9,10,12-15$ \\
\hline USDA $193(=$ OB3) & $.9,10,12,-15$ \\
\hline USDA 194 (= PRC 194). & $9,10,12-15$ \\
\hline USDA 201 (= PRC 201). & $.9,10,12-15$ \\
\hline USDA $205^{\mathrm{T}}\left(=\right.$ PRC $\left.205^{\mathrm{T}}=\operatorname{ATCC} 35423^{\mathrm{T}}\right)$ & $9,10,12-15$ \\
\hline USDA $206(=$ PRC 206 $) \ldots \ldots \ldots \ldots \ldots$ & $9,10,12-14$ \\
\hline USDA 208 (= PRC 208). & $9,12,13,15$ \\
\hline USDA 214 (= PRC 214). & $9,1213,15$ \\
\hline USDA 217 (= PRC 217). & $9,12,13,15$ \\
\hline USDA 257. & .13 \\
\hline
\end{tabular}

lose. Litmus milk reactions are variable for acid and alkali, but most strains exhibit peptonization and reduction of litmus.

All strains are susceptible to gentamicin $(30 \mu \mathrm{g} / \mathrm{ml})$, rifampin $(5 \mu \mathrm{g} / \mathrm{ml})$, neomycin $(100 \mu \mathrm{g} / \mathrm{ml})$, and streptomycin $(10$ $\mu \mathrm{g} / \mathrm{ml})$. All strains are resistant to penicillin $\mathrm{G}(50 \mu \mathrm{g} / \mathrm{ml})$. Resistance to kanamycin is variable at a concentration of 20 $\mu \mathrm{g} / \mathrm{ml}$, but all strains are susceptible to $50 \mu \mathrm{g}$ of kanamycin per $\mathrm{ml}$.

Large plasmids have been demonstrated in all strains. Some of the plasmids contain DNA regions that hybridize with probes for the nifD and nifH genes from Klebsiella pneumoniae. Plasmids involved in nodulation have also been identified. The levels of DNA-DNA homology with type strains $R$. meliloti ATCC $9930, R$. trifolii ATCC $14480, R$. leguminosarum ATCC 10004, $R$. phaseoli ATCC 14482, and $B$. japonicum ATCC 10324 range from 5 to $43 \%$.

Effective nodules are formed on Glycine max cv. Peking (soybean), Glycine soja (wild soybean), Vigna unguiculata (cowpea), and Cajunus cajan (pigeon pea). An ineffective symbiosis is formed on Macroptilium atropurpureum (siratro), Macroptilium lathyroides (phasey bean), Sesbania cannabina, Vigna radiata (mung bean), and United States cultivars of Glycine max (soybean). Leucaena leucocephala (Haole Koa), Medicago sativa (alfalfa), Trifolium repens (white clover), Trifolium pratense (red clover), Astragalus sinicus (milkvetch), and Arachis hypogaea (peanut) are not nodulated.

The type strain of $R$. fredii is strain USDA 205, a culture of which has been deposited in the American Type Culture Collection as strain ATCC 35423. This strain conforms to the above description of the species. The levels of DNA hybridization with $R$. meliloti ATCC $9930^{\mathrm{T}}$ ( $\mathrm{T}=$ type strain $), R$. trifolii ATCC $14480^{\mathrm{T}}, R$. phaseoli $\mathrm{ATCC} 14482^{\mathrm{T}}, R$. leguminosarum ATCC $10004^{\mathrm{T}}$, and $B$. japonicum ATCC $10324^{\mathrm{T}}$ are $14,18,7,5$, and $8 \%$, respectively.

Within $R$. fredii, there appear to be two distinct subgroups which can be differentiated on the basis of DNA-DNA hybridization, acid production on YEM broth, kanamycin resistance, and serology. As a result, we propose two new chemovars, Rhizobium fredii chemovar fredii chemovar nov. and Rhizobium fredii chemovar siensis chemovar nov. Additional strains for which hybridization data are unavailable but serotyping has been done indicate that other serogroups exist (B. Bohlool, personal communication) and may warrant additional chemovar designations. These strains should be considered members of $R$. fredii chemovar unknown until more data are available.

$R$. fredii chemovar fredii is in accordance with the descrip- tion of the species. The strains of this chemovar are susceptible to kanamycin $(20 \mu \mathrm{g} / \mathrm{ml})$, do not reduce litmus, and produce a final $\mathrm{pH}$ of less than 6.1 in YEM broth after 4 days of incubation at $28^{\circ} \mathrm{C}$. The levels of DNA-DNA homology with strains USDA $205^{\mathrm{T}}\left(=\right.$ ATCC $\left.35423^{\mathrm{T}}\right)$ and USDA 201 are 91 to 96 and 24 to $63 \%$, respectively. Included in this chemovar are strains USDA 193 and USDA 206 and type strain USDA 205.

$R$. fredii chemovar siensis is in accordance with the above description of the species and can be differentiated on the basis of kanamycin resistance $(20 \mu \mathrm{g} / \mathrm{ml})$, reduction of litmus, and a final $\mathrm{pH}$ in YEM broth of more than 6.1. The levels of DNA-DNA homology with strains USDA 201 and USDA $205^{\mathrm{T}}\left(=\right.$ ATCC $\left.35423^{\mathrm{T}}\right)$ are 95 and 24 to $53 \%$, respectively. Included in this chemovar are strain USDA 194 and the type strain of the chemovar, strain USDA 201.

This research was supported in part by grant 701-15-25 from the U.S. Department of Agriculture Cooperative Research Service, by grant USDA-SEA-CR 701-15-51 under Agency for International Development program PASA AG/TAB 610-9-76, and by a grant from the Memphis State University Faculty Research Grant Fund.

We thank J. A. Moorefield for technical assistance, W. E. C. Moore for advice in preparation of the manuscript, and $\mathrm{H}$. $\mathrm{H}$. Keyser for depositing the type strain with the American Type Culture Collection.

\section{LITERATURE CITED}

1. Brewin, N. J., J. E. Beringer, and A. W. B. Johnston. 1980. Plasmid-mediated transfer of host-range specificity between two strains of Rhizobium leguminosarum. J. Gen. Microbiol. 120:413-420.

2. Buchanan-Wollaston, A. V., J. E. Beringer, N. J. Brewin, P. R. Hirsch, and A. W. B. Johnston. 1980. Isolation of symbiotically defective mutants in Rhizobium leguminosarum by insertion of the transposon Tn5 into a transmissable plasmid. Mol. Gen. Genet. 178:185-190.

3. Dixon, R. O. D. 1969. Rhizobia, with particular reference to relationships with plant hosts. Annu. Rev. Microbiol. 23:137158.

4. Graham, P. H. 1976. Identification and classification of root nodule bacteria, p. 99-112. In P. S. Nutman (ed.), Symbiotic nitrogen fixation in plants. Cambridge University Press, London.

5. Jarvis, B. D. W., C. E. Pankhurst, and J. J. Patel. 1982. Rhizobium loti, a new species of legume root nodule bacteria. Int. J. Syst. Bacteriol. 32:378-380.

6. Jordan, D. C. 1982. Transfer of Rhizobium japonicum Buchanan 1980 to Bradyrhizobium japonicum gen. nov., a genus of slow-growing, root nodule bacteria from leguminous plants. Int. J. Syst. Bacteriol. 32:136-139.

7. Jordan, D. C. 1984. Family III. Rhizobiaceae Conn, 1938 p. 234-244. In N. R. Kreig and J. G. Holt (ed.), Bergey's manual of systematic bacteriology, 9th ed., vol. 1. The Williams \& Wilkins Co., Baltimore.

8. Jordan, D. C., and O. N. Allen. 1974. Family III. Rhizobiaceae Conn, 1938, p. 261-264. In R. E. Buchanan and N. E. Gibbons (ed.), Bergey's manual of determinative bacteriology, 8th ed. The Williams \& Wilkins Co., Baltimore.

9. Keyser, H. H., B. B. Bohlool, T. S. Hu, and D. F. Weber. 1982. Fast-growing rhizobia isolated from root nodules of soybeans. Science 215:1631-1632.

10. Masterson, R. V., P. R. Russell, and A. G. Atherly. 1982. Nitrogen fixation (nif) genes and large plasmids of Rhizabium japonicum. J. Bacteriol. 152:928-931.

11. Nuti, M. P., A. A. Lepidi, R. K. Prakash, R. A. Schilperoort, and F. C. Cannon. 1979. Evidence for nitrogen fixation (nif) genes on indigenous Rhizobium plasmids. Nature (London) 282:533-535.

12. Sadowsky, M. J., and B. Ben Bohlool. 1983. Possible involve- 
ment of a megaplasmid in nodulation of soybeans by fastgrowing rhizobia from China. Appl. Environ. Microbiol. 46:906-911.

13. Sadowsky, M. J., H. H. Keyser, and B. Ben Bohlool. 1983. Biochemical characterization of fast- and slow-growing rhizobia that nodulate soybeans. Int. J. Syst. Bacteriol. 33:716-722.

14. Scholla, M. H., J. H. Moorefield, and G. H. Elkan. 1984. Deoxyribonucleic acid homology between fast-growing soybean- nodulating bacteria and other rhizobia. Int. J. Syst. Bacteriol. 34:283-286.

15. Stowers, M. D., and A. R. J. Eaglesham. 1984. Physiological and symbiotic characteristics of fast-growing Rhizobium japonicum strains. Plant Soil 77:3-14.

16. Yelton, M. M., S. S. Yang, S. A. Edie, and S. T. Lim. 1983. Characterization of an effective salt-tolerant, fast-growing strain of Rhizobium japonicum. J. Gen. Microbiol. 129:1537-1547. 